\title{
Hegemonic Domination of White over Black in "The Bluest Eye" by Toni Morrison
}

\author{
* Irfan Mehmood, PhD Scholar (Corresponding Author) \\ ** Dr. Komal Ansari, Assistant Professor \\ *** Dr. M. K. Sangi, Professor
}

\begin{abstract}
Every human being is beautiful with his own colour and appearance. No colour makes one beautiful but the white people of America have propagated the idea of white beauty as a tool of their politics to show themselves superior to the blacks. They focused on the colour because to be white for a black is unattainable as it is biological. They also tried to create self-hatred among the blacks by spreading the white ideology. They hegemonized the blacks to accept the concept of white beauty by using advertisements, media, actors and education. They also forced the blacks to be considered as ugly creating the least opportunities in the work places for the black community of America; alienating them from the society and torturing them both mentally and physically. As in The Bluest Eye, Pecola and her family are the worst victims of white men's politics. Pecola together with her family members is both mentally and physically tortured and tormented to accept the white ideology. However, Pecola and her mother have accepted the white ideology and Pecola has mostly desired to get the bluest eye. On the other hand, Claudia resisted against the white men and their ideology. At the end, Pecola has accepted the baby of Cholly Breedlove as a token of love and self-reliance and both Claudia and Frieda wish to have the safe delivery of it. Therefore, in this article I would like to show that how the white men employed their evil intention of using the colour for dominating the blacks in America as a part of power politics, and also show black people's reaction toward the white ideology with reference to The Bluest Eye by Toni Morrison.
\end{abstract}

Keywords: Colour, Domination, Hegemony, White ideology, and Resistance.

Introduction

To the white American, yellow hair, pink skin and blue eyes are the symbol of standard beauty. The white people believe that pale white skin, blonde hair and blue eyes are the only features, which make one beautiful, and beautiful women have the right to achieve everything glorious in the materialistic world. They can fulfill all their dreams and desires. They get everything as they wish. They deserve the high place in the society too. They can also rule all over the world. That is why in the novel, The Bluest Eye, Pecola was completely obsessed with fair skin, blonde hair and not only for blue eyes but also for the bluest eyes.

The white Americans used the concept of beauty as a part of their politics to dominate the blacks who belonged to the working class. They imposed the idea on the blacks that to be beautiful, one should be white in colour. If someone is black, he is not beautiful. They selected the physical shape of the human being as measurement of one's beauty. In The Bluest Eye, Claudia disclosed the white man's politics by saying "Adults, older girls, shops, magazines, newspapers, window signs-all the world had agreed that a blue-eyed, yellow-haired, pink- skinned doll was what every girl child treasured. Here, they said, this is beautiful, and if you are on this day "worthy' you may have it" (Morrison, 197, p. 14).

The white people spread the concept of white beauty throughout America in such a way that almost all the American believe that only the white people are beautiful and the rest of the people are ugly. The white media also support the concept of white beauty so that the black people can easily

\footnotetext{
* Institute of English Language \& Literature, University of Sindh, Jamshoro, Pakistan Email: irfanmehmoodkhan1982@gmail.com

** Institute of English Language \& Literature, University of Sindh, Jamshoro, Pakistan Email: komal.ansari@usindh.edu.pk

*** Institute of English Language \& Literature, University of Sindh, Jamshoro, Pakistan. Email: khansangi@usindh.edu.pk
} 
accept the idea. They precisely politicize the concept of beauty to dominate the black completely in America.

This article will focus on the reasons for choosing colour as a tool of the white man's politics to dominate the blacks. The White people enslaved African blacks, tortured, and tormented them in America. Though the black people were strong in physical power but still they were dominated by the white people. In order to dominate them completely, the educated and cunning white people hegemonized the blacks with their skin colour and embedded in their minds that whites are beautiful and blacks are ugly. Therefore, they are inferior to the white American. To convince the blacks, the whites have chosen colour because it is biological fact. It is quite impossible for the blacks to become white in reality and to get yellow hair and the bluest eye. If the white could use any other thing like money, knowledge or physical power as a standard of beauty, the black could attain this. As it was just unattainable for the black, they chose colour as the standard of beauty.

Blacks were unable to get the standard of beauty by obtaining pink skin, yellow hair and blue eyes. Therefore, they thought that they were not beautiful and so they are ugly. The novel The Bluest Eye focused on the idea of supposed ugliness of the black people to the eyes of the white people of America. The entire Breedlove family believes that they are ugly. The whites considered themselves to be superior to blacks, as they were white in colour. Since the black people as Pecola and Pauline were neglected everywhere in America, they started hating themselves. As Manuela Lopez Ramirez said that, "In The Bluest Eye the dissociation of the female adolescent identity stems from the colonization of Blacks by mainstream culture and the internalization of its standards of beauty, which engender self-hatred" (Ramirez 2013, p.82).

Hating her own color, Pecola wants to be a beautiful woman obtaining the bluest eye to escape from the negligence of the American white people. Pecola feels that she can overcome this battle of self-hatred by obtaining the bluest eyes. As Claudia said that, "Each night, without fail, she prayed for blue eyes. Fervently, for a year she had prayed" (Morrison, 1979, p.35).

Even Pecola's mother Pauline has internalised the notion that black are not beautiful. She does not like to pass her time with her family members rather she feels comfort working in a white man's house. Thus, the black started hating them nourishing the concept of white beauty. As the blacks hated themselves for not being beautiful, the white people were able to dominate them easily.

Educational Institution is the place where everyone can get the views of his basic rights. It makes one conscious of good and evil. It is a matter of sorrow that Pecola, a black girl, cannot enjoy her basic rights in the school where she gets admitted. Both the white teachers and students have abused her bitterly. In her school, she is not able to meet the other students except Claudia and Frieda. Rather, the white children humiliate her. They also mock at herby saying, "Booby loves Pecola Breedlove! Booby loves Pecola Breedlove!" (Morrison, 1979, p.34).

Even Pocola's ugliness makes her ignored and despised at school by teachers and classmates. She is the only member of her class who sits alone at a double dark. Here teacher never tries to glance at her and calls on her when everyone was required to respond as we find that "They tried never to glance at her, and called on her only when everyone was required to respond."(Morrison, 1979, p.34). In school, white children get the first priority from theteachers.On the other hand, teachers neglected the black children so that they could not be educated properly. Thus, the white people used education and educational institution as a tool to hegemonize the black that they are ugly and they cannot be as equal as the white people in every sphere of life.

In working place, white people took the significant position whereas the black took the lower post like servants, cleaners, etc. They also under took hard labours and heavy construction jobs. The whites were the employers and blacks were employees. As, in The Bluest Eye Pauline has been working as a servant in the white man's house for a longtime. Being as ervant, she becomes very happy. Even she likes to pass her time working in the white man's family hating to live with her husband and children, as she has not in a good relation with her husband who usually beats her without finding any valid reason. When she found an adorned house of a white man, she became very happy and inwardly dreams to get so. However, it was very difficult for the black like Pauline to get such a beautiful house and family like her white master. That is why she is highly convinced to feel herself as inferior to the white. Claudia said that, "It was her good fortune to find a permanent job in the home of a well-to-do family whose members were affectionate, appreciative, and generous. She looked at their houses, smelled their linen, touched their silk draperies, and loved all of 
it."(Morrison,1979, p.98). Thus, creating very poor opportunities in the job market for the blacks, the white people enforced the blacks to neglect themselves and consider the white as superior to the black.

Film industry plays a very significant role to dominate the black people in America. Pecola was also greatly influenced and highly motivated by the white actors and actresses. In the film industry, the white were grabbing the major characters and the black were playing the role of minor characters. Gaeta Garbo,Ginger Rogers and Shirley Temple were white actresses. The whites were super stars and the black acted as servants or other minor characters. The black people were not able to show their talent playing a vital role in any film because the white people didn't give the black any kind of opportunity to get the higher position in the film so that they could not develop the concept of achieving the higher position in the society. Rather they were shown as servant or hard working man and woman to be mentally dominated and to think the mass unskilled and poor. There were lots of advertisements of white models. On the other hand, the blacks were not selected to become a model of advertisement. So, they were bound to gaze at the white models in different advertisements. Pecola was greatly influenced by the beauty and popularity of Shirley Temple. Shirley Temple with her hallmark dimples, corkscrew golden curls and twinkling blue eyes was the highest paid child actress of the 1903's and the early 1904's. When Pecola moves in with Claudia, she finds a Shirley Temple mug. She begins to drink out of it at every opportunity, she gets thinking that it will make her beautiful and make her look like the beautiful girl she sees in front of her. As Claudia said that, "She was along time with the milk, and gazed fondly at the silhouette of Shirley Temple's dimpled face. Frieda ad she had a loving conversation about how cute Shirley Temple was."(Morrison, 1979, pp.12$13)$.

Thus a black girl like Pecola hopes to get the white skin, considering that the white girl like Shirley Temple is more beautiful than her. Pecola and Frieda were also fond of the white baby doll. The white people used the blue eyed baby doll as a weapon to impress black children. They showed the blue eyed baby doll as the most significant gift of the Christmas day and the most cherished thing of a girl child. It became the symbol of white beauty. That is why most of the girls desired to have it as their Christmas gift. Being a black child Pecola liked the blue-eyed baby doll very much. She was very curious to have it as the white politics had greatly influenced her. The white tried to allure the black making the blue eyed baby doll popular to every white girl even to the black. They institutionalized the concept of white beauty using the mainstream media, magazines and newspapers. As Claudia said that, "Adults, older girls, shops, magazines, newspapers, window signs-all the world had agreed that a blue-eyed, yellow-haired, pink-skinned doll was what every girl child treasured. (Morrison, 1979, p. 14).

Pecola and her mother are hegemonized to accept the whites as beautiful and consider themselves ugly. It is because they are not white in colour and they don't have blue eyes to be considered as beautiful. Pecola becomes very excited to have blueeyes and her mother Pauline wants to pass most of her time in the house of her white mistress. Thus the white people of America become successful to hegemonize blacks to accept the white ideology and culture.

In many cases, the whites tortured and tormented black people to accept the white ideology and to consider themselves as ugly. The black people are not really ugly, rather they are forced to be considered as ugly. In America, the black people were the worst victims of racism. When we go through the fiction, we find that Pecola has been forced to be treated as ugly though she was not ugly in the real sense of the term. Wherever she went, she did not get any opportunity to explore her talent because she was forcefully separated from the mainstream culture of America because of her blackness. Even she did not get any help from the light colored people. Though they were not completely white in color, they feel superior to the black as Maureen considers herself as more beautiful than Pecola. And almost all the time she tries to insult Pecola saying that, "Safe on the other side, she screamed at us, I am cute! And Youugly! Black and ugly black emos. I am cute!" (Morrison, 1979, p.56).

Pecola was disliked by the light colored Maureen, rather she was tortured and tormented because of her black color. Pecola experienced the most horrible incident of her life, when she met a white boy Junior. When Junior allured her saying that he wanted to show her a new thing, she accepted the proposal as she was not proposed by any white boy ever. But taking her in his house, he tried to humiliate her and torment her physically. He killed his own cat though Pecola tried to save 
her. When His mother came back he showed Pecola as a murderer of the cat. His mother bitterly criticized Pecola saying that, "Get out, she said, her voice quite. You nasty little black bitch. Get out of my house." (Morrison, 1979, p.72).

Even when she became very crazy to have the bluest eye after being physically and mentally tortured by white men, she went to Soaphead Church and got nothing. Rather, she was again humiliated by the religious man, as he used her to kill the dog and then he became completely frustrated and hopeless to get the bluesteye. Like Pecola, her father Cholly, was also tortured and tormented by the white people at the time of his boyhood, when he was forced to have a physical relation with a lady before the eyes of some white men. Being a black man he was not able to show his talent in the society where he lived rather he was also the worst victim of racism as he did not get any job to maintain his wife and children. He was frustrated and that is why he became a drunken and could not maintain his family properly. Thus the black people in America were physically and mentally tormented by the white people to be considered as ugly.

The white men alienated the black people in the white community using the white ideology and power. When the black had not any other option to live and to sustain in the society, they willingly or unwillingly accepted the idea of the white man and stared believing that they are ugly and they are worthless. So they are not able to be liked by anyone. Pecola believes that she is ugly and that is why, she is disliked by everyone in her society, rather she is tortured and tormented by everyone, including her own family.To escape from suchcondition, she wants to get the bluest eyes and thus she wants to be a beautiful girl. When Pecola went to Junior's house she becomes very happy watching such a beautiful house and she desired to possess such beautiful things in her own house. But it was quite impossible because she does not find any good relation between her father and mother, rather they always quarrel because Cholly is disappointed as he has no satisfactory job to earn money. So, he is a drunken and is not careful about his wife and children rather he wants to pass his unhappy time of his life. On the other hand, her mother is not satisfied with her father too as she like sthe house of the white master. Though she is beaten by her husband, but still she does not leave her husband because she has no other place to go. So she has accepted suchincident of unhappy life as her regular activities. As they live in a very unwanted condition in white society, Pocola's brother is not also a happy young boy that is why he becomes very violent. He does not like to stay at home rather when he becomes angry, he usually breaks the goods of his own house. Though Cholly, Pecola and her brother have talent, they are not able to show it because of white man politics as they are segregated, and they are not able to get the proper education. They are not able to get any help from religion, society and government. They have become completely failure in their lives and they are bound to be treated as ugly and worthless.

Most of the blacks accepted the concept of beauty of the white people in America, as they become motivated by the white ideology and power. The whole Breedlove family accepted the concept of white people and their philosophy and that is why Pecola and her family members think that they are ugly. Among them Pecola and her mother started changing their own identity and culture. As Pecola wants to be treated as a beautiful possessing the bluest eyes and her mother started hating her own family and culture considering the white men and their house is suitable to live and pass her time. But some of them did not accept the concept of white beauty. Claudia is one of them. Claudia boldly rejects to have blue eyes, white skin, straight hair to be a beautiful woman rather she thinks that she is a beautiful woman with her natural appearance. She also rejects the social status that the white people enjoyed in white society. Claudia is a revolutionary figure in fiction. She doesn't like to change her identity and culture rather she is very happy with her ownself. She does not like Pecola and Frieda who are very happy to have the white doll as a Christmas gift rather she said that"I destroyed white baby dolls."(Morrison,1979, p.15).

She does not like the white skin and the white baby doll which symbolizes white beauty. The white people used it as a part of their politics to convince the black girl to accept the white ideology. As a part of revolution and resistance to the white ideology and culture, she does not like the white baby doll. Even she does not like to meet the white girl because they feel themselves as superior to the black. However, Claudia does not like such kind of superiority that is why she violently reacts against the white girl saying that, "When she comes out of the car we will beat her up, make red marks on her white skin, and she will cry and ask us do we want herto pull her pants down" (Morrison, 1979, p. 5). 
Being tortured and tormented both mentally and physically by the white men, black people understood that they should come forward to save their own rights in America. That is why Claudia does not accept the white people's culture and ideology rather she tries to save Pecola whenever she faces problems. When Maureen bitterly criticized Pecola, Claudia came forward to save Pecola and started abusing Maureen. It is because when they will be united they can achieve theirgoal. As a black writer, Toni Morrison also tried to teach the black the importance of self-reliance showing Claudia as a revolutionary girl. Even when no one likes Pocola, she is liked by Choly and he madethe physical relation with Pecola twice to satisfy her dream to be liked by someone. Even all the black people were not upset after hearing Pocola's pregnancy. As both Claudia band Frieda, were very excited to see Pecola's safe delivery. They were not shocked at finding Pocola as a pregnant, rather they usually discussed the matter and once decided to pray to God so that Pecola could bring birth her new baby. They also planted marigold and waited for the last time and when Pecola lost her baby they became upset too. Pecola herself has not accepted the fact - the loss of her baby normally and consequently she became mad.

\section{Conclusion}

As Toni Morrison is a black writer, she is quite aware of the sufferings of the black people in America. She expresses her inner feelings through The Bluest Eye. She has shown that how the concept of beauty, employed by the white people as part of power politics, can destroy one's life. Throughout the novel the author tries to show the techniques used by the white people to dominate the black in America. A critic Dr. Neelam Bhardwaj says:

The life of life of African-American women had been affected by racism, sexism and classicism. These so-called systems of social and psychological restrictions were put on the Africans living in that countrywhenthecolouredpeoplewereregardedas inferiors. As the blacks were relegated to a lower class by virtue of their race, women were related to a separate caste by virtue of their sex. In the same way, black women were also victimized not only on the basis of races and sex but they were also badly treatedbyclassexploitationswhichwasthegreatest oppression of blacks in America. (Bhardwaj, 2016, p.103)

As an American citizen, Pecola has a right to get almost all the facilities to explore her talent, but she has not got a little bit opportunities from white society, people and the government. Wherever she goes, she suffers a lot. She did not get the proper education because of the worst racial environment in the school where she was bitterly abused by the students and teachers. Instead of getting friendship, she was tortured by the white boy Junior, in the school. At home, she was also the victim of white politics. As her father was a jobless drunken man, he did not get any opportunity to live his life with his family members with peace ratherhe was also the victim of the white man's lust. The white people of America also used almost all the cultural institutions of America to convince the blacks to be considered as ugly, to be considered as inferior to the whites and to accept the white as their master. To hegemonize the blacks, the whites used the black man and woman as the insignificant characters in the cinema, advertisement and magazine whereas the white played the significant role in almost all media. Having being influenced by the white politics, Pecola and her mother have been very crazy to accept the whitemen's ideas and culture as their own. Pocola's mother started hating her family and her house whereas Pocola wants to get the bluest eye to be a beautifull ady in the society led by the white people. However, being an author of fiction, Toni Morrison did not accept the white politics of using colour as a way of segregation. That is why throughout the mouth of Claudia, the narrator of fiction, Morrison resists the concept of white beauty and culture. From the very beginning to the end of the text, Claudia does not support Pocola and Frieda's affection toward the love of white beauty and culture rather she hates the white man and their concept of white beauty and that is why she said that she did not like the white baby doll. Even she likes Pocola and her baby too, though most of the white people think that Pocola's baby is unwanted. As a black author, Toni Morrison was successful to focus on the white man's politics of dominating the black people in America hegemonizing them. If it was needed, the white also enforced the black to be dominated. No white man, woman, and the government did come forward to help the black community of America to give them their basic rights. That is why as a conscious woman, Toni Morrison boldly and precisely portrayed the real picture of the black people of America through portraying the pathetic picture of the Breedlove family and finally through portraying Pocola, the worst victim of the white poetics in America. 


\section{References}

Ahmad. A. (2000). In theory: Classes, nations, and literature. London, New York: Verso.

Allen, Walter R. (1995). African-American Family Life in Societal Context: Crisis and Hope. In. Sociological Forum, Vol. 10, No. 4, Special Issue: African-Americans and Sociology: A Critical Analysis. Springer.

Althusser, L. (1976). On the Reproduction of Capitalism. London: New Left Books.

Bhardwaj, N. (2016). TheBluestEye: A Tragedy of Oppression and Internalized Racism, International Journal on Studies in English Language and Literature (IJSELL) Volume 4, Issue 8, August 2016, PP 101-104 ISSN2347-3126 (Print) \& ISSN 2347-3134 (Online) <https://www.arcjournals.org/pdfs/ijsell/v4-i8/14.pdf>

Morrison, T. (1979). The Bluest Eye. London: Vintage Books.

Muhammad, E. (1965). A Message to the Blackman in America. Chicago: The Final Call Publishing.

Nazir, F. (2015). Master Critical Notes on Toni Morrison. Lahore: College Book Depot. New York: Oxford University Press.

Ramirez, Manuela L. (2013). The theme of the shattered self in Toni Morison's The Bluest Eye and A Mercy, Miscelanea: A Journal of English and American Studies 48: pp. 75-91 ISSN: 11376368. 